\title{
Dukungan Teman Sebaya dan Kematangan Karier Mahasiswa Tingkat Akhir
}

\author{
Novia Hendayani ${ }^{1}$, Sri Muliati Abdullah ${ }^{2}$ \\ ${ }^{1,2}$ Fakultas Psikologi Universitas Mercu Buana Yogyakarta \\ e-mail : ${ }^{1}$ 171194@gmail.com, ${ }^{2}$ muliatiyogya@gmail.com
}

\begin{abstract}
Abstrak. Mahasiswa yang memiliki kematangan karier akan memudahkan memperoleh pekerjaan yang diharapkan. Penelitian ini bertujuan untuk mengetahui hubungan antara dukungan teman sebaya dengan kematangan karier pada mahasiswa tingkat akhir di Universitas " $X$ ". Hipotesis yang diajukan adalah ada hubungan positif antara dukungan teman sebaya dengan kematangan karier pada mahasiswa tingkat akhir di Universitas "X". Subjek penelitian ini adalah mahasiswa tingkat akhir Universitas "X"yang berada pada semester 7 ke atas dan berusia antara 21-24 tahun sebanyak 110 subjek. Hasil penelitian dianalisis dengan teknik korelasi product moment. Hasil korelasi menunjukkan $\mathrm{r}=0,545(\mathrm{p}<0,05)$ hal ini berarti ada hubungan positif antara dukungan teman sebaya dengan kematangan karier pada mahasiswa tingkat akhir di Universitas "X". Mahasiswa yang mampu mempersepsi positif dukungan teman sebayanya yang berupa dukungan emosional, dukungan penghargaan, dukungan instrumental, dan dukungan informasi, maka mahasiswa dapat memiliki perencanaan karier, mengetahui sumber-sumber eksplorasi, mampu mendapatkan informasi karier, mampu melakukan pengambilan keputusan karier, dan memiliki orientasi realitas yang baik. Dukungan teman sebaya memberikan sumbangan efektif sebesar $29,7 \%$ terhadap kematangan karier, sedangkan 70,3\% diberikan oleh faktor lain.
\end{abstract}

Kata kunci : dukungan teman sebaya, kematangan karier

Abstract. Students with career maturity will make it easier to get the job expected. This study aims to determine the relationship between peer support and career maturity in the final grade students at the " $X$ " University. The hypothesis proposed was that there was a positive relationship between peer support and career maturity in the final grade students at " $X$ " University. The subject of this research was the final level of the University of " $X$ " which is in the 7th and above semester and aged between 21-24 years as many as 110 subjects. The results was analyzed by product moment correlation technique. The result of correlation showed $r=0,545(p<0,05)$ this indicates that there was positive relation between peer support with career maturity at final level student at " $X$ " University. Students who able to positively perceive peer support in the form of emotional support, award support, instrumental support, and information support, students can have career planning, know exploration resources, be able to get career information, be able to make career decisions, and have orientation good reality. Peer support provides $29,7 \%$ effective contribution to career maturity, while 70,3\% is given by other factors.

Keywords : career maturity, peers support

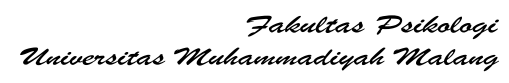


Pada era globalisasi, perkembangan ilmu pengetahuan dan teknologi yang sangat pesat menuntut individu untuk memilih karier yang sesuai dengan minat, kemampuan dan sesuai dengan harapan. Semakin banyak peluang dan tantangan untuk pemilihan dan penentuan karier di era globalisasi ini, apabila terjadi kesalahan dalam pemilihan dan pemutusan karier, maka karier yang diperoleh pun tidak sesuai yang diharapkan (Hidayati, 2015).

Mahasiswa adalah SDM potensial yang dihadapkan pada persaingan meraih peluang kerja yang kompetitif.. Mahasiswa yang nantinya lulus dari bangku perkuliahan akan dihadapkan pada masalah ketatnya persaingan dunia kerja. Tingginya tuntutan dunia usaha ditunjukkan melalui hasil survei yang menyebutkan bahwa 91\% kalangan dunia usaha beranggapan lulusan perguruan tinggi tidak siap pakai selepas kuliah (Kasih dan Suganda, dalam Rachmawati, 2012). Hal ini terjadi dikarenakan banyaknya kasus di kalangan mahasiswa yang minat kerjanya tidak sesuai dengan bakat dan minat yang mereka miliki. Selain itu, terdapat banyak mahasiswa yang masih bingung tentang apa yang akan mereka kerjakan dalam hidupnya setelah tamat dari perguruan tinggi. Kondisi ini disebabkan oleh kurangnya bekal ilmu, keterampilan dan pengalaman yang dimiliki oleh seorang mahasiswa ketika ia akan memasuki dunia kerja (Rachmawati, 2012).

Lestari \& Raharjo mendapati fenomena para sarjana yang baru lulus belum sepenuhnya mempertimbangkan kemampuan, minat, dan kepribadiannya dalam memilih suatu pekerjaan. Para sarjana cenderung memilih suatu pekerjaan didasarkan pada rasa khawatir dan cemas bila terlalu lama menganggur, adanya rasa malu pada lingkungan disekitar terutama jika belum memperoleh pekerjaan, dan adanya tuntutan moral dari orangtua. Jika hal ini terus-menerus dibiarkan maka akan berdampak pada dirinya dan juga pada perusahaan dimana ia bekerja kelak. Karena pekerjaan yang dipilih jauh dari latar belakang pendidikan sehingga berakibat kurang memiliki skill yang memadai dalam menjalankan pekerjaan (Lestari dan Rahardjo, 2013).

Problem-problem di atas menunjukkan permasalahan dalam kematangan karier. Peneliti melakukan preliminary untuk melihat tingkat kematangan karier pada mahasiswa tingkat akhir dengan melakukan wawancara terhadap 15 mahasiswa tingkat akhir di Universitas "X". Berdasarkan hasil wawancara yang telah dilakukan pada tanggal 20 April 2016 di Universitas " $X$ ", hasilnya menunjukan: a) 6 dari 15 mahasiswa kurang memiliki perencanaan karier yang baik di masa depan; b) 9 dari 15 mahasiswa kurang memiliki keterampilan untuk melakukan eksplorasi terhadap diri terkait karier; c) 4 dari 15 mahasiswa kurang memiliki informasi yang cukup tentang dunia kerja; d) 11 dari 15 mahasiswa merasa belum bisa menentukan pilihan karier/ mengambil keputusan tentang karier yang sesuai dengan bakat dan kemampuannya; dan e) 11 dari 15 mahasiswa belum memiliki gambaran tentang karakteristik, persyaratan, kemampuan, dan keterampilan yang dibutuhkan dalam pekerjaan, serta prospek pekerjaan untuk masa depan kariernya. 
Berdasarkan hasil wawancara di atas, dapat disimpulkan bahwa mahasiswa tingkat akhir di Universitas "X"memiliki kematangan karier yang rendah. Rendahnya kematangan karier mahasiswa tingkat akhir ini ditunjukkan dengan kurang memiliki perencanaan karier yang baik, kurang melakukan eksplorasi karier, kurang memiliki informasi mengenai karier, dan kurangnya kemampuan dalam pengambilan keputusan karier. Selain itu mahasiswa tingkat akhir juga kurang memiliki pengetahuan yang baik akan dirinya dan pengetahuan akan dunia kerja.

Rendahnya kematangan karier dapat menyebabkan kesalahan dalam mengambil keputusan karier karena tidak memiliki pengetahuan akan dirinya (kemampuan dan potensi yang dimilikinya) dan pengetahuan akan pekerjaan Lestari dan Rahardjo (2013). Brown dan Brooks (dalam Handayani, 2015), menyebutkan bahwa kematangan karier akan berdampak pada kesiapan seseorang untuk membuat pilihan karier termasuk didalamnya mengenai studi lanjutan. Mahasiswa dengan kematangan karier yang rendah akan merasa kebingungan dalam menentukan pilihan karier yang tepat. Ariati (2016) menambahkan, apabila kematangan karier tidak muncul dan berkembang hingga remaja, akan memungkinkan terjadinya ketidakpuasan kerja dan kelak akan berganti-ganti pekerjaan, tanpa pernah memperoleh pengetahuan diri (self knowledge) serta pengetahuan tentang dunia kerja yang diperlukan untuk mengambil suatu keputusan.

Menurut teori perkembangan karier yang dikemukakan oleh Super (dalam Savickas, 2001) mahasiswa tingkat akhir berada pada tahap pelaksanaan (implementation), yaitu dimulai dari usia 21 sampai dengan usia 24 tahun. Pada tahap ini mahasiswa seharusnya sudah mulai menyelesaikan pendidikan atau beberapa pelatihan serta memulai pekerjaan yang relevan. Menurut Malik (2015) pemilihan bidang pekerjaan berkaitan erat dengan penentuan program pendidikan, karena suatu bidang pekerjaan menuntut seseorang untuk menyelesaikan pendidikan dan pelatihan tertentu sesuai dengan tuntutan pekerjaan tersebut.

Mahasiswa yang nantinya lulus dari perguruan tinggi diharapkan memiliki kematangan karier yang baik agar dapat mengambil keputusan pilihan karier dengan tepat. Hal ini didukung oleh pernyataan Crites (dalam Zulkaida, 2007) bahwa untuk dapat memilih karier yang tepat, dibutuhkan kematangan karier yaitu pengetahuan akan diri, pengetahuan tentang pekerjaan, kemampuan memilih pekerjaan, dan kemampuan merencanakan langkah-langkah menuju karier yang diharapkan. Mahasiswa yang memiliki kematangan karier yang tinggi akan memilih karier yang sesuai dengan latar belakang pendidikan yang ditempuhnya sehingga membuat mereka tidak lagi bingung dalam menentukan karier yang akan ditempuh setelah lulus dari bangku kuliah (Nasriyah, 2013). Oleh karena itu kematangan karier penting untuk dimiliki mahasiswa tingkat akhir. 
Zunker (2008), mendefinisikan kematangan karier sebagai kemampuan untuk membuat keputusan karier mandiri dan bertanggung jawab berdasarkan integrasi bijaksana informasi terbaik yang tersedia tentang diri sendiri dan dunia kerja. Gonzalez (2008), menyatakan bahwa kematangan karier merupakan kematangan individu yang disesuaikan dengan tahap perkembangannya dengan melihat kesesuaian antara tahap kematangan individu dengan usia kronologisnya. Lal (2014), menyatakan bahwa kematangan karier merupakan kapabilitas individu dalam menguasai tugas perkembangan karier yang sesuai dengan tahapan perkembangannya. Berdasarkan penjelasan teori di atas, dapat disimpulkan bahwa kematangan karier adalah kemampuan individu dalam menguasai tugas perkembangan karier sesuai dengan tahap perkembangan karier meliputi perencanaan karier, melakukan eksplorasi terkait karier, mencari informasi, dan memiliki kemampuan pengambilan keputusan karier yang realistik dan konsisten.

Super (dalam Gonzalez, 2008), menyebutkan kematangan karier terdiri dari lima aspek, yaitu perencanaan karier, eksplorasi karier, informasi, pengambilan keputusan, dan orientasi realitas. Perencanaan karier (career planfulness) adalah kesadaran individu bahwa dirinya harus membuat pilihan pendidikan dan karier, serta mempersiapkan diri untuk memasuki karier tertentu. Eksplorasi karier (career exploration) adalah proses yang menunjukkan individu mengadakan penyelidikan atau menggali segala informasi mengenai dunia kerja yang diperlukannya dari berbagai sumber yang ada. Informasi (information) adalah adanya sikap individu mencari informasi dan pengetahuan mengenai pendidikan, pekerjaan atau karier serta dapat menggunakan informasi tersebut. Pengambilan keputusan (decision making) adalah kemampuan individu dalam pengambilan keputusan tentang karier yang sesuai dengan kemampuannya. Orientasi realitas (reality orientation) adalah individu memiliki pengetahuan yang baik akan dirinya, individu mampu berpikir dengan realistik, individu mampu menunjukkan sikap yang konsisten, dan individu memiliki pengalaman kerja yang memadai.

Kematangan karier dipengaruhi oleh faktor-faktor dalam diri (internal) dan faktor luar diri (eksternal). Seligman (1994) menjelaskan beberapa faktor yang dapat mempengaruhi perkembangan karier individu dimana perkembangan karier akan menentukan kematangan karier. Faktor-faktor tersebut adalah (a) faktor internal individu memiliki pengaruh yang kuat pada kematangan karier seseorang, hal ini mencakup self esteem, kemampuan, minat, kepribadian, dan prestige. Adanya kesesuaian antara kemampuan, minat, dan bakat seseorang dengan persyaratan bidang yang dipilihnya, akan mempengaruhi tingkat kepuasan, kinerja, dan stabilitas mereka; (b) faktor keluarga dapat menyebabkan terjadinya kematangan karier, dalam hal ini anggota keluarga dapat memberikan pengaruh bagi remaja dalam menentukan dan memilih bidang pekerjaan yang diinginkan (Rice, 1993); dan (c) faktor sosial ekonomi, mencakup lingkungan yang dapat mempengaruhi kematangan karier. Penelitian ini difokuskan pada salah satu sumber pengaruh lingkungan sosial yaitu pengaruh teman sebaya. Menurut Mappiare (dalam Mustikaningsih, 2015), bahwa lingkungan sosial pertama dimana remaja belajar

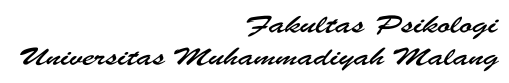


untuk hidup bersama dengan orang lain yang bukan keluarganya adalah teman sebaya. Lingkungan teman sebaya merupakan suatu kelompok yang baru, yang memiliki ciri, norma, dan kebiasaan yang jauh berbeda dengan apa yang ada dalam lingkungan mahasiswa.

Teman sebaya merupakan sumber dukungan emosional penting sepanjang transisi masa remaja (Papalia, dkk, dalam Sasmita dan Rustika 2015). Selain itu Tarakanita (2001) mengatakan bahwa, teman sebaya selain merupakan sumber referensi bagi remaja mengenai berbagai macam hal, juga dapat memberikan kesempatan bagi remaja untuk mengambil peran dan tanggung jawab yang baru melalui pemberian dorongan (dukungan sosial). Menurut Berndt \& Perry (dalam Berk, 2009) remaja mulai mengandalkan teman sebaya dibandingkan orang tua untuk mendapatkan kedekatan dan dukungan. Dukungan teman sebaya didefinisikan sebagai memberikan dan menerima bantuan, berdasarkan pemahaman bersama, menghormati dan saling memberdayakan orang-orang yang berada dalam situasi serupa yaitu melalui dukungan, persahabatan, empati, saling berbagi, dan saling memberi bantuan psikologis (Mead dalam Faulkner, dkk, 2013). Dukungan teman sebaya diduga menjadi salah satu faktor penting yang dapat mempengaruhi kematangan karier. Terlebih pada masa ini remaja lebih banyak menghabiskan waktunya dengan teman sebaya dibanding keluarganya. Intensitas dan waktu yang dihabiskan bersama teman lebih besar pada masa remaja dibandingkan waktu lain dalam rentang kehidupan (Papalia, dkk, dalam Sasmita dan Rustika 2015).

Pada penelitian ini bentuk-bentuk dukungan teman sebaya mengacu pada bentuk-bentuk dukungan sosial menurut Sarafino (2007), yaitu dukungan emosional, dukungan penghargaan, dukungan instrumental, dan dukungan informasi. Dukungan emosional yaitu berupa empati, kepedulian, perhatian, penilaian positif, dan memberikan semangat kepada individu yang bersangkutan. Dukungan penghargaan yaitu dukungan yang melibatkan ekspresi yang berupa pernyataan setuju dan penilaian positif terhadap ide-ide, perasaan dan performa orang lain. Dukungan instrumental yaitu berupa bantuan langsung seperti bantuan materi, finansial atau hal-hal yang secara nyata dibutuhkan oleh individu yang bersangkutan. Dukungan informasi yaitu berupa pemberian nasehat, instruksi, saran, arahan, masukan, atau pemberian informasi mengenai hal-hal yang dibutuhkan individu.

Bentuk-bentuk dukungan teman sebaya dapat mempengaruhi kematangan karier. Mahasiswa yang mendapat bantuan dalam bentuk emosional seperti perhatian, peduli dan semangat, penghargaan atas aspirasi yang dilakukan, mendapat bantuan langsung, dan informasi yang relevan dengan kebutuhannya, kemudian jika bantuan-bantuan yang didapatkan dapat memberikan makna positif bagi dirinya, maka mahasiswa mampu menyelesaikan tugas-tugas perkembangan karier dengan baik sesuai dengan tahapan perkembangan karier sehingga tercapai adanya kematangan karier. 
Berdasarkan permasalahan di atas, diketahui bahwa dukungan teman sebaya dapat mempengaruhi kematangan karier mahasiswa tingkat akhir. Oleh karena itu, penelitian ini berusaha untuk mengetahui apakah ada hubungan antara dukungan teman sebaya dengan kematangan karier pada mahasiswa tingkat akhir di Universitas "X"? Manfaat teoritis penelitian ini adalah menambah khasanah temuan ilmiah dalam Psikologi Karier. Manfaat praktis jika hipotesis penelitian ini terbukti, mampu memberikan penegasan bahwa dukungan teman sebaya dapat digunakan untuk memodifikasi kematangan karier mahasiswa, misal melalui pelatihan dukungan karier teman sebaya (career peer support) ataupun dapat menjadi dasar sosialisasi bagi para mahasiswa di kampus untuk dapat saling memberikan dukungan untuk dapat mewujudkan lulusan dengan kematangan karier yang baik.

\section{METODE}

Penelitian ini menggunakan dasar rancangan penelitian kuantitatif. Subjek penelitian adalah mahasiswa tingkat akhir di Universitas "X"sebanyak 110 subjek. Kriteria atau ciri-ciri subjek dalam penelitian ini adalah:

a. Subjek penelitian termasuk dewasa awal, yaitu subjek yang berusia antara 21 hingga 24 tahun.

b. Subjek merupakan mahasiswa tingkat akhir (semester 7 ke-atas/angkatan 2013 ke atas) yang dirasa telah mampu untuk mengambil keputusan pilihan karier yang tepat untuk dituju setelah lulus dari perguruan tinggi.

Pengambilan subjek penelitian dilakukan berdasarkan teknik Purposive Sampling yaitu pemilihan sekelompok subjek didasarkan atas ciri-ciri atau sifat-sifat tertentu yang dipandang mempunyai sangkut paut yang erat dengan ciri-ciri atau sifat-sifat dari populasi itu sendiri (Hadi, 2000).

Variabel tergantung (dependent variable) penelitian ini adalah kematangan karier adalah kemampuan individu dalam menguasai tugas perkembangan karier sesuai dengan tahap perkembangan karier meliputi perencanaan karier, melakukan eksplorasi terkait karier, mencari informasi, dan memiliki kemampuan pengambilan keputusan karier yang realistik dan konsisten. Kematangan karier akan diukur dengan menggunakan skala yang disusun berdasarkan aspek-aspek kematangan karier yang dikemukakan oleh Super (dalam Gonzalez, 2008) yaitu: (a) perencanaan karier, (b) sumber-sumber eksplorasi, (c) informasi, (d) pengambilan keputusan, dan (e) orientasi realitas. Peneliti mengukur tingkat kematangan karier dengan skala yang dibuat oleh peneliti sendiri. Semakin tinggi skor subjek, maka semakin tinggi tingkat kematangan karier. Sebaliknya semakin rendah skor subjek, maka semakin rendah tingkat kematangan karier.

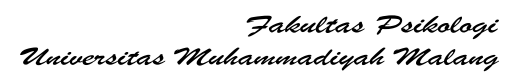


Variabel bebas (independent variable) penelitian ini adalah dukungan teman sebaya adalah persepsi individu mengenai pemberian bantuan yang diberikan oleh teman sebaya baik berupa verbal maupun non verbal dalam bentuk dukungan emosional, penghargaan, instrumental, dan informasi. Dukungan teman sebaya ini diukur dengan menggunakan skala dukungan teman sebaya yang disusun oleh peneliti sendiri dengan mengacu pada bentuk-bentuk dukungan sosial yang dikemukakan oleh Sarafino (2007), yaitu: (a) dukungan emosional, (b) dukungan penghargaan, (c) dukungan instrumental, dan (d) dukungan informasi. Peneliti menggunakan skala untuk mengukur dukungan teman seabaya dengan skala yang dibuat oleh peneliti sendiri. Penyusunan skala ini berdasarkan bentuk-bentuk dukungan sosial dari Sarafino. Semakin tinggi skor subjek, maka semakin positif persepsi mahasiswa terhadap dukungan teman sebaya. Sebaliknya, semakin rendah skor subjek, maka semakin negatif persepsi mahasiswa terhadap dukungan teman sebaya.

Koefisien validitas (koefisien korelasi aitem-total) aitem skala kematangan karier bergerak dari 0,304-0,525 dan koefisien reliabilitas alpha sebesar 0,883. Koefisien validitas aitem skala dukungan teman sebaya bergerak dari 0,311-0,737 dan koefisien reliabilitas alpha sebesar 0,919. Metode yang digunakan untuk menguji hipotesis penelitian ini adalah teknik korelasi Product Moment dari Pearson. Keseluruhan data dianalisis dengan menggunakan program SPSS (Statistical Program for Social Science) versi 16.

\section{HASIL}

Analisa statistik dalam penelitian ini dibagi dalam 2 tahap yaitu tahap uji prasyarat dan uji hipotesis (lihat tabel 1). Uji prasyarat yang harus terpenuhi yaitu variabel yang diukur harus mendekati sebaran normal dan memiliki hubungan yang linier antara variabel bebas dan variabel tergantung (Sugiyono, 2015). Uji normalitas menggunakan uji Kolmogorov Smirnov-Z menunjukkan nilai 0,712 dengan $p<0,05$. Hal ini berarti sebaran data tidak normal. Meski demikian, mengacu pada pendapat Priyatno (2010) mengatakan bahwa data yang banyaknya lebih dari 30 maka dapat dikatakan terdistribusi dengan normal dan biasa disebut sampel besar. Data dalam penelitian ini menggunakan subjek sebanyak 110 subjek, sehingga data dapat dikatakan terdistribusi normal dan penelitian dapat dilanjutkan. Uji normalitas pada data Kematangan karier menunjukkan nilai 0,081 dengan $\mathrm{p}>0,05$. Hal ini berarti sebaran data Kematangan karier, normal. Uji linieritas menunjukkan nilai $\mathrm{F}=55,281$, berarti hubungan kedua variabel linier. 
Dukungan emosional adalah bantuan yang diberikan kepada individu dalam bentuk empati, seperti peduli, perhatian, hal positif, dan memberikan semangat kepada individu yang bersangkutan. Jika teman sebaya memberikan bantuan berupa empati (peduli, perhatian, hal positif, dan semangat), dan bantuan tersebut memberikan makna positif bagi mahasiswa, maka mahasiswa mampu mengatasi kesulitan-kesulitan yang dialami dalam menyelesaikan tugas-tugas perkembangan karier hingga akhirnya dapat mencapai kematangan karier. Sebaliknya jika teman sebaya tidak memberikan bantuan berupa empati (peduli, perhatian, dan semangat), ataupun memberikan dukungan emosional namun bantuan/dukungan tersebut tidak memberikan makna positif, maka mahasiswa kurang mampu mencapai kematangan karier.

Jika teman sebaya memberikan dukungan penghargaan seperti pernyataan setuju atau penilaian positif atas ide-ide, perasaan dan performa, kemudian jika bantuan tersebut memberikan makna positif, maka mahasiswa dapat memiliki kematangan karier yang baik. Misalnya dengan memiliki kematangan karier yang baik, mahasiswa dapat melakukan perencanaan karier dengan baik. Sebaliknya, jika teman sebaya tidak memberikan bantuan penghargaan seperti yang telah disebutkan, maka mahasiswa kurang memiliki kematangan karier. Begitu pun jika teman sebaya memberikan dukungan penghargaan namun dukungan /bantuan tersebut tidak memberikan makna positif, maka mahasiswa kurang dapat mencapai kematangan karier yang baik.

Dukungan instrumental adalah bantuan langsung seperti materi, finansial atau hal-hal yang secara nyata dibutuhkan oleh individu yang bersangkutan. Jika teman sebaya memberikan bantuan seperti hal-hal yang secara nyata dibutuhkan oleh mahasiswa dan bantuan tersebut dapat memberikan makna positif, maka mahasiswa mampu mencapai kematangan karier. Sebaliknya jika teman sebaya tidak memberikan bantuan berupa materi atau hal-hal yang secara nyata dibutuhkan, maka mahasiswa kurang mampu mencapai kematangan karier. Begitu pun jika teman sebaya memberikan bantuan seperti materi atau finansial namun bantuan tersebut tidak memberikan makna positif, maka mahasiswa kurang mampu mencapai kematangan karier yang baik.

Dukungan informasi adalah pemberian bantuan berupa pemberian nasehat, instruksi, saran, arahan, masukan, atau pemberian informasi mengenai hal-hal yang dibutuhkan individu. Jika teman sebaya memberikan bantuan berupa informasi yang relevan dengan karier yang diminati mahasiswa, dan bantuan tersebut memberikan makna positif atau bermanfaat, maka mahasiswa mampu mencapai kematangan karier. Misalnya dengan memiliki kematangan karier, maka mahasiswa dapat mengambil keputusan karier berdasarkan informasi yang didapatnya. Sebaliknya jika teman sebaya tidak memberikan bantuan informasi terkait karier yang diminati mahasiswa, maka mahasiswa kurang mampu mencapai kematangan karier. Begitu pun jika teman sebaya memberikan bantuan 
informasi terkait karier yang diminati mahasiswa namun tidak memberikan makna positif bagi dirinya, maka mahasiswa kurang memiliki kematangan karier yang baik.

Berdasarkan hasil kategorisasi skor kematangan karier menunjukkan bahwa terdapat 73 $(66,37 \%)$ mahasiswa yang berada dalam kategori tinggi dan sisanya $37(33,63 \%)$ berada dalam kategori sedang. Hal ini menunjukkan bahwa sebagian besar mahasiswa tingkat akhir mempunyai kematangan karier yang tinggi. Tingginya kematangan karier yang dimiliki mahasiswa tingkat akhir ini ditunjukkan dengan data hasil penelitian yaitu tingginya minat mahasiswa untuk merencanakan karier, eksplorasi karier, mencari informasi pekerjaan yang sesuai dengan latar belakang pendidikan, memiliki kemampuan dalam mengambil keputusan karier, dan memiliki pengetahuan yang baik mengenai potensinya untuk berkarier.

Hasil kategorisasi skor dukungan teman sebaya menunjukkan bahwa terdapat 67 $(60,90 \%)$ mahasiswa yang berada dalam kategori positif, dan sisanya $43(39,10 \%)$ berada dalam kategori netral. Hal ini menunjukkan bahwa dukungan teman sebaya yang didapatkan positif. Dukungan teman sebaya seperti pemberian motivasi, pernyataan setuju atau tanggapan positif, meminjamkan barang (handphone atau laptop), dan pemberian informasi pekerjaan tersebut dapat memberikan makna positif atau bermanfaat bagi mahasiswa dalam mencapai karier yang diinginkannya.

Hasil penelitian ini sesuai dengan hasil penelitian yang dilakukan oleh Jemini dan Gashi (2013), menyatakan bahwa kematangan karier berkorelasi positif dengan dukungan sosial. Remaja akhir dengan dukungan teman sebaya yang tinggi menunjukkan tingkat kematangan yang lebih tinggi untuk berkarier. Menurut Ferry (dalam Jemini dan Ghasi, 2013), remaja yang tidak mendapat dukungan sosial salah satunya dari teman sebaya, mengalami kesulitan untuk mengambil keputusan pilihan karier.

Hasil penelitian lain yang dilakukan oleh Nashriyah (2014) menyatakan bahwa terdapat hubungan positif antara dukungan sosial keluarga dengan kematangan karier pada mahasiswa. Semakin tinggi dukungan sosial keluarga maka akan semakin meningkatkan kematangan karier, begitupun sebaliknya. Remaja yang mendapatkan dukungan sosial yang tinggi akan mempunyai pikiran lebih positif terhadap situasi yang sulit dibandingkan dengan remaja yang memiliki tingkat dukungan sosial yang rendah. Berdasarkan hasil penelitian ini, menunjukkan bahwa terdapat hubungan positif antara dukungan teman sebaya dengan kematangan karier pada mahasiswa tingkat akhir di Universitas " $X$ ". Semakin positif dukungan teman sebaya, maka semakin tinggi kematangan karier. Sebalinya, semakin negatif dukungan teman sebaya, maka semakin rendah kematangan karier. 


\section{SIMPULAN DAN IMPLIKASI}

Berdasarkan hasil penelitian yang diperoleh, dapat diambil kesimpulan bahwa ada hubungan positif antara dukungan teman sebaya dengan kematangan karier pada mahasiswa tingkat akhir di Universitas " $X$ ". Semakin tinggi dukungan teman sebaya, maka semakin tinggi kematangan karier yang dimiliki mahasiswa tingkat akhir. Sebaliknya, semakin rendah dukungan teman sebaya, maka semakin rendah kematangan karier yang dimiliki mahasiswa tingkat akhir. Dukungan teman sebaya memberikan sumbangan efektif sebesar $29,7 \%$ terhadap kematangan karier, sedangkan $70,3 \%$ diberikan oleh faktor lain.

Implikasi penelitian ini bagi mahasiswa tingkat akhir Universitas " $\mathrm{X}$ ", dapat mengoptimalkan kematangan kariernya dengan mencari informasi mengenai karier yang sudah dipilih, melakukan eksplorasi diri dengan bertanya kepada orang lain yang ahli di bidang karier, dan mengikuti pelatihan-pelatihan yang dapat memaksimalkan bakat dan kemampuan yang dimilikinya.

Implikasi bagi arah penelitian selanjutnya yaitu dapat melakukan penelitian serupa dengan meluaskan area subjek penelitian tidak hanya di satu universitas, dapat melakukan di jenjang pendidikan yang berbeda, misal di tingkat pendidikan SMA, SMK, ataupun Diploma, dan dapat melibatkan variabel bebas yang lain misalnya harga diri, minat, kepribadian, bakat, dukungan dari sumber sosial yang lain misal keluarga

\section{REFERENSI}

Ariati, M. J. (2016). Hubungan antara kelekatan terhadap teman sebaya dengan kematangan karier pada siswa kelas XI SMK Negeri 1 Trucuk Klaten. Jurnal Empati, 5(4), 705-710.

Berk, L. E. (2009). Human development. New York: McGraw-Hill.

Faulkner, A., Hughes, A., Thompson, S., Nettle, M., Wallcraft, J. Collar, J. De la Haye, S., McKinley, S. (2013). Mental health peer support in england: piecing together the jigsaw. Diunduh dari : https://www.mind.org.uk/media/418953/Peer-Support-Report-Peerfest 2013.pdf. tanggal 03 Agustus 2017.

Hadi, S. (2000). Metodologi research. Yogyakarta: Andi Offset Yogyakarta. 
Handayani, W. (2015). Hubungan antara konsep diri dengan kematangan karier pada mahasiswa Fakultas Bahasa Indonesia semester akhir Universitas PGRI Palembang. Jurnal Fakultas Psikologi. Palembang: Universitas Bina Darma. Diunduh dari http://digilib.binadarma.ac.id/files/disk1/135/123-123wulanhanda-6701-1-jurnalw-i.pdf. tanggal 01 Desember 2016.

Hidayati, R. (2015). Layanan informasi karier membantu peserta didik dalam meningkatkan pemahaman karier. Jurnal Konseling GUSJIGANG, 1(1), 1-10.

Jemini, L. dan Gashi. (2013). Social support and career maturity of kosovar adolescents. Research and Education Challenges Toward The Future. ICRAE. ISSN: 23080825: $1-9$.

Lal, K. (2014). Career maturity in relation to level of aspiration in adolescents. American International Journal of Research in Humanities, Arts and Social Sciences, 5(1), 113-118.

Lestari, T. N., Rahardjo, P. (2013). Hubungan antara kecerdasan emosional dengan kematangan karier pada mahasiswa Universitas Muhammadiyah Purwokerto yang sedang menempuh skripsi. PSYCHO IDEA, (2), 1-9.

Malik, L.R. (2015). Kematangan karier mahasiswa Jurusan Tarbiyah Sekolah Tinggi Agama Islam Negeri (STAIN) Samarinda. Fenomena, 7(1), 111-129.

Mead, S., Hilton, D., \& Curtis, L. (2001). Peer support : A theoretical perspective. Psychiatric Rehabilitation Journal, 25(2), 134-141.

Nashriyah, S. Q., Yusuf, M., \& Karyanta, N. A. (2014). Hubungan antara penyesuaian diri dan dukungan sosial keluarga dengan kematangan karier pada mahasiswa Program Studi Ilmu Komunikasi FSIP UNS. Jurnal Ilmiah Psikologi Candra Jiwa, 2(5), 195-205.

Priyatno, D. (2010). Teknik mudah dan cepat melakukan analisis data penelitian dengan SPSS. Yogyakarta: Gava Media.

Rachmawati, Y. E. (2012). Hubungan antara self efficacy dengan kematangan karier pada mahasiswa tingkat awal dan tingkat akhir di Universitas Surabaya. Jurnal Ilmiah Mahasiswa Universitas Surabaya, 1(1), 1-25.

Rice, F.P. (1993). The Adolescent, Development, Relationship \& Culture (ed 9). USA : Allyn \& Bacon. 
Salim, O. (1999). Distribusi normal. Jurnal Kedokteran Trisakti. Vol. 18, (2); 107-111.

Sarafino, E. P. (2007). Health psychology biopsychosocial interaction (ed.6). New York: John Willey dan Sons, Inc.

Sarafino, E. P dan Smith, T. W. (2010). Health psychology : biopsychology interactions (ed. 7). United States of America.

Sasmita, I. \& Rustika, I. M. (2015). Peran efikasi diri dan dukungan sosial teman sebaya terhadap penyesuaian diri mahasiswa tahun pertama Program Studi Pendidikan Dokter Fakultas Kedokteran Universitas Udayana. Jurnal Psikologi Udayana, 2(2), 280-289.

Savickas. M. L. (2001). A developmental perspective on vocational behaviour: career patterns, salience, and themes. International Journal for Educational and Vocational Guidance, 1, 49 - 57.

Seligman. (1994). Developmental career counselling and assessment (ed.6). California : SAGE Publications.

Sugiyono. (2015). Metode penelitian kuantitatif, kualitatif, dan $R \& D$. Bandung: Alfabeta.

Tarakanita, I. (2001). Hubungan status identitas etnik dengan konsep diri mahasiswa. Jurnal Psikologi, 7(1): 1-14.

Wikipedia. (2016). Wikipedia karier. Diunduh dari : https://id.wikipedia.org/wiki/Karier tanggal 29 November 2016.

Zulkaida, A., Kurniati, Taganing., N. M., Retnaningsih, Muluk, H., dan Rifameutia. (2007). Pengaruh locus of control dan efikasi diri terhadap kematangan karier siswa Sekolah Menengah Atas (SMA). Proceeding PESAT (Psikologi, Ekonomi, Sastra, Arsitek dan Sipil). 2, 1- 4.

Zunker, V.G. (2008). Career counselling : a holistic approach (ed.7). USA: Thomson Brooks/Cole Publishing Company. 